\title{
Analysis of $O$-Phosphoamino Acids in Proteins by Gas Chromatography with Flame Photometric Detection
}

\author{
Hiroyuki Kataoka, ${ }^{*}$ Yukizo Ueno and Masami Makita \\ Faculty of Pharmaceutical Sciences, Okayama University, \\ Tsushima, Okayama 700, Japan \\ Received December 10, 1990
}

\begin{abstract}
A sensitive and selective method was developed for the analysis of $O$-phosphoserine (P-Ser), $O$-phosphothreonine (P-Thr) and $\boldsymbol{O}$-phosphotyrosine (P-Tyr) in proteins by gas chromatography (GC). After partial acid and base hydrolysis of the protein samples, the liberated $O$-phosphoamino acids were converted into their $N$-isobutoxycarbonyl trimethyl ester derivatives and measured by GC with flame photometric detection (FPD-GC), using a DB-1701 capillary column. The calibration lines were linear in the range of $0.1-5 \mathrm{nmol}$ for P-Ser and P-Thr, and in the range of $0.05-1 \mathrm{nmol}$ for P-Tyr, and the detection limits for P-Ser, P-Thr and P-Tyr were about $0.26,0.18$ and $0.30 \mathrm{pmol}$ as injection amounts, respectively. The best hydrolysis conditions for the proteins proved to be $6 \mathrm{M} \mathrm{HCl}$ at $110^{\circ} \mathrm{C}$ for 2 hr to analyze P-Ser and P-Thr, and $5 \mathrm{M} \mathrm{KOH}$ at $130^{\circ} \mathrm{C}$ for $1 \mathrm{hr}$ to analyze P-Tyr. $O$-Phosphoamino acids in the protein hydrolyzates could be selectively determined by the FPD-GC method without any influence from other amino acids. This method was applied to the analysis of $O$-phosphoamino acids in several commercial proteins.
\end{abstract}

Post-translational modification of proteins by the formation of phospho-monoesters of serine, threonine and tyrosine residues is an important mechanism for the control of diverse intracellular events. ${ }^{1,2)}$ These $O$-phosphoamino acids have been found in a number of proteins $^{1-3)}$ and peptides. ${ }^{4,5)}$ Measurement of the $O$-phosphoamino acid content in proteins is important both to correlate the protein structure with its function and to suggest the kind of protein kinase that regulates the protein activity.

The separation and determination of $O$ phosphoamino acids has previously been carried out by thin-layer chromatography, ${ }^{6-9)}$ high-voltage electrophoresis, ${ }^{6,10-12)}$ amino acid analysis ${ }^{13-15)}$ and high-performance liquid chromatography (HPLC) ${ }^{16-25)}$ after acid, base or enzymatic hydrolysis of the phosphoproteins. However, some of these methods have resulted in a lengthy separation time, ${ }^{6,13,17,21,24)}$ poor resolution ${ }^{7,16,19,20)}$ or low sensitivity. ${ }^{19,21)}$ Moreover, most of these methods require ${ }^{32} \mathrm{P}$-labeling to detect and quantify $O$-phosphoamino acids, and are of limited usefulness for detecting endogenously phosphorylated amino acids. Therefore, a method without the use of radioactivity is required for the quantitation of endogenous $O$-phosphoamino acid residues in proteins.

Recently, we have developed a convenient and reliable method for determining aminoalkylphosphates by gas chromatography (GC) with flame ionization detection (FID), in which these compounds were analyzed as their $\mathrm{N}$-isobutoxycarbonyl methyl ester derivatives. ${ }^{26)}$ In the present work, we investigated a selective and sensitive method for analyzing $O$-phosphoamino acids in proteins by $\mathrm{GC}$ with flame photometric detection (FPD). Using this method, the $O$-phosphoamino acid content in several commercial proteins was measured.

\section{Materials and Methods}

Materials. O-Phospho-L-serine (P-Ser), O-phospho-DLthreonine (P-Thr) and $O$-phospho-L-tyrosine $(\mathrm{P}-\mathrm{Tyr})$ were obtained from Sigma (St. Louis, MO, U.S.A.). 2-Amino4-phosphonobutyric acid (APB) and 2-amino-7-phosphonoheptanoic acid (APH) as internal standards (I.S.) were also obtained from Sigma. Each compound was dissolved 
in water to make up a stock solution at a concentration of $1 \mathrm{~mm}$. Purified commercial proteins, albumin (bovine serum), ovalbumin (chicken egg), $\alpha$-casein (bovine milk), $\beta$-casein (bovine milk), $\kappa$-casein (bovine milk), phosivitin (egg yolk), hemoglobin (human), cytochrome $c$ (bovine heart), protamine (salmon sperm), histone (calf thymus), myelin basic protein (bovine brain), alcohol dehydrogenase (yeast), catalase (bovine liver), lysozyme (egg white) and chymotrypsin (bovine pancreas), were obtained from Sigma. Isobutyl chloroformate was obtained from Tokyo Kasei Kogyo (Tokyo, Japan). $N$-Methyl- $N$-nitroso-ptoluenesulphonamide to generate diazomethane was obtained from Nacalai Tesque (Kyoto, Japan), all other chemicals being of analytical grade.

Acid hydrolysis. For the P-Ser and P-Thr analyses, the proteins were hydrolyzed in an acid. An aliquot of the protein sample $(0.004-2 \mathrm{mg})$ was placed in a $5 \times 50-\mathrm{mm}$ glass test tube, and $50 \mu 1$ of $20 \mu \mathrm{M}$ APB (I.S.) was added. The mixture was dried in a Model RD-41 centrifugal evaporator (Yamato Kagaku, Tokyo, Japan), and hydrolyzed with $0.2 \mathrm{ml}$ of $6 \mathrm{M} \mathrm{HCl}$ in the vapor phase for 2 hr at $110^{\circ} \mathrm{C}$ with a Pico-Tag workstation (Waters Assoc., Milford, MA, U.S.A.). The resulting hydrolyzate was extracted twice with $0.5 \mathrm{ml}$ of distilled water, the extracts being transferred to another reaction tube (10-ml Pyrex glass tube with a PTFE-lined screw cap), and then used for the analyses.

Base hydrolysis. For the P-Tyr analysis, the proteins were hydrolyzed in a base. An aliquot of the protein sample $(0.2-4 \mathrm{mg})$ was placed in a $9 \times 75-\mathrm{mm}$ polypropylene tube, and $50 \mu \mathrm{l}$ of $4 \mu \mathrm{m} \mathrm{APH}$ (I.S.) was added. After adding $0.2 \mathrm{ml}$ of $10 \mathrm{M} \mathrm{KOH}$, the total volume was made up to $0.4 \mathrm{ml}$ with distilled water if necessary. The mixture was then hydrolyzed for $1 \mathrm{hr}$ at $130^{\circ} \mathrm{C}$ in the Pico-Tag workstation. To the resulting hydrolyzate was added $0.2 \mathrm{ml}$ of $8 \mathrm{M} \mathrm{HCl}$, before the solution was transferred to the reaction tube, and used for the analysis.

Conversion. O-Phosphoamino acids in the acid and base hydrolyzates of the proteins were converted as previously described. ${ }^{26)}$ After the hydrolyzate sample had been adjusted to $\mathrm{pH} 10$ with $2 \mathrm{M} \mathrm{NaOH}$ if necessary, $0.1 \mathrm{ml}$ of isobutyl chloroformate was added. The mixture was agitated in a shaker set at $300 \mathrm{rpm}$ (up and down) for $10 \mathrm{~min}$ at room temperature. The reaction mixture was then acidified to $\mathrm{pH} 1-2$ with $2 \mathrm{M} \mathrm{HCl}$ and extracted with $3 \mathrm{ml}$ of diethyl ether in order to remove the excess reagent, the ethereal extract being discarded. The aqueous layer was saturated with $\mathrm{NaCl}$ and then extracted twice with $3 \mathrm{ml}$ of diethyl ether containing 10\% 2-propanol. The pooled ethereal extracts were methylated by bubbling diazomethane, which was generated according to the micro-scale procedure of Schlenk and Gellerman, ${ }^{27)}$ through this solution until a yellow tinge became visible. After standing at room temperature for $5 \mathrm{~min}$, the solvents were evaporated to dryness at $80^{\circ} \mathrm{C}$ under a stream of dry air. The residue was finally dissolved in $0.1 \mathrm{ml}$ of ethyl acetate, and $1 \mu \mathrm{l}$ of this solution was injected into the gas chromatograph.

Gas chromatography $(G C)$. GC analysis was carried out with a Shimadzu 14A gas chromatograph equipped with a flame ionization detector and flame photometric detector (P-filter). A fused-silica capillary column $(15 \mathrm{~m} \times 0.53 \mathrm{~mm}$ i.d., $1.0 \mu \mathrm{m}$ film thickness) with cross-linked DB-1701 (J \& W, Folson, CA, U.S.A.) was used. The operating conditions were as follows: column temperatures, $210^{\circ} \mathrm{C}$ (for P-Ser and P-Thr) and $270^{\circ} \mathrm{C}$ (for P-Tyr); injection and detection temperatures, $260^{\circ} \mathrm{C}$ (for P-Ser and P-Thr) and $290^{\circ} \mathrm{C}$ (for P-Tyr); and nitrogen flow-rate, $10 \mathrm{ml} / \mathrm{min}$. The peak heights of the $O$-phosphoamino acids and the I.S. (APB or APH) were measured, and the peak height ratio against the I.S. was calculated for each to construct a calibration line.

Determination of the total phosphate content in protein. Protein was completely hydrolyzed in $5 \mathrm{M} \mathrm{KOH}$ at $150^{\circ} \mathrm{C}$ for $12 \mathrm{hr}$. The total phosphate released from the protein was measured by the method of Itaya et al. ${ }^{28}$ using malachite green.

\section{Results and Discussion}

\section{Gas chromatographic analyses of $O$-phosphoa- mino acids}

The $O$-phosphoamino acids could be conveniently converted into their $\mathrm{N}$-isoBOC trimethyl ester derivatives as previously described. ${ }^{26)}$ As shown in Figs. $1 \mathrm{~A}$ and $2 \mathrm{~A}$, each compound gave a single and symmetrical peak from GC with a DB-1701 capillary column. Other phosphorus compounds such as sugar phosphates and nucleic acid phosphates were not detected by this method. The $O$ phosphoamino acid derivatives provided an excellent FPD response, the minimum detectable amount per injection of P-Ser, P-Thr and $\mathrm{P}$-Tyr to give a signal three times as high as the noise under our instrumental conditions being about $0.26,0.18$ and $0.30 \mathrm{pmol}$, respectively. The FPD-GC method described here was over 200 times more sensitive than our FID-GC method previously reported, ${ }^{26)}$ and provided higher sensitivity than the HPLC methods with fluorometric detection. APB and APH were used as the I. S. for the P-Ser and P-Thr analyses, and for the P-Tyr analysis, respec- 


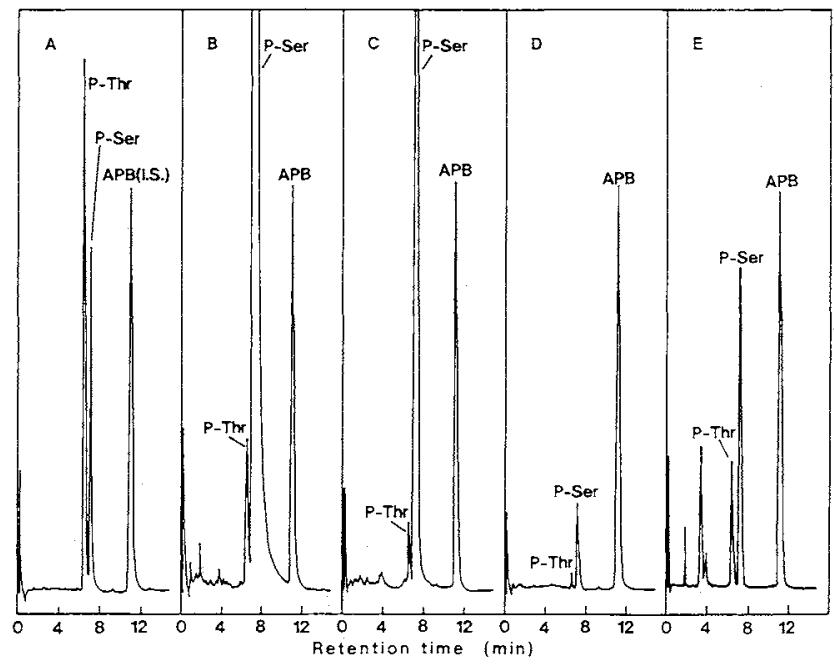

Fig. 1. Chromatograms Obtained from a Standard Solution and Acid Hydrolyzates of Protein Samples by FPD-GC.

(A) standard (containing $1 \mathrm{nmol}$ of each compound), (B) $\alpha$-casein $(0.5 \mathrm{mg})$, (C) phosvitin $(0.01 \mathrm{mg})$, (D) histone $(0.8 \mathrm{mg}),(\mathrm{E})$ myelin $(0.25 \mathrm{mg})$. The GC conditions are given in the experimental section. Attenuation: $10 \times 16$.

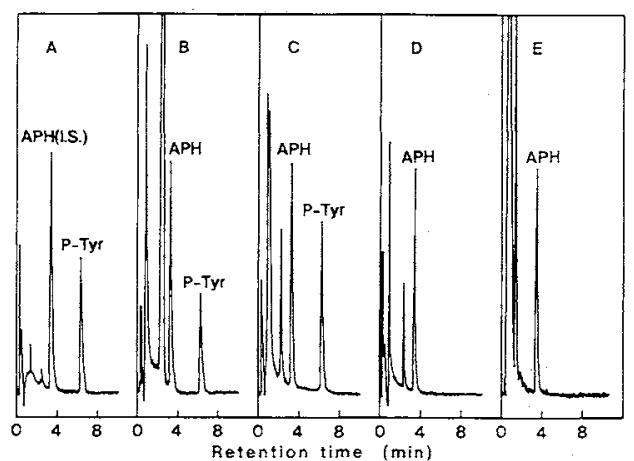

Fig. 2. Chromatograms Obtained from a Standard Solution and Base Hydrolyzates of Protein Samples by FPD-GC.

(A) standard (containing 0.2 nmol of each compound), (B) $\alpha$-casein $(2.0 \mathrm{mg}),(\mathrm{C})$ phosvitin (1.3 $\mathrm{mg}),(\mathrm{D})$ histone $(2.7 \mathrm{mg}),(\mathrm{E})$ myelin $(1.0 \mathrm{mg})$. The $\mathrm{GC}$ conditions are given in the experimental section. Attenuation: $10 \times 8$.

tively. In order to test the linearity of the calibration lines, $\mathrm{P}-\mathrm{Ser}$ and $\mathrm{P}-\mathrm{Thr}$ in the range $0.1-5 \mathrm{nmol}$ and P-Tyr in the range $0.05-1 \mathrm{nmol}$ were converted, and one hundredth amounts of the derivatives were injected for GC. In each case, a linear relationship was obtained, the regression lines for P-Ser, P-Thr and P-Tyr being $y=0.783 x-0.028 \quad(r=0.9940, n=18)$, $y=1.409 x-0.060(r=0.9996, n=18)$ and $y=$ $3.406 x-0.032(r=0.9993, n=15)$, respectively, where $y$ is the peak height ratio and $x$ is the amount (nmol) of each compound.

\section{Acid and base hydrolysis of the protein samples}

The $O$-phosphate linkages of serine and threonine residues are defined by their stability to acids and lability to bases. Therefore, acid hydrolysis routinely used to study the identity and amounts of P-Ser and P-Thr in peptides and proteins. However, a variety of conditions have been applied with respect to the concentration of $\mathrm{HCl}$, time and temperature. In the present investigation, we studied the acid hydrolysis conditions for phosvitin (containing P-Ser, P-Thr and P-Tyr) with a $6 \mathrm{M} \mathrm{HCl}$ gas phase. As shown in Fig. 3, the maximal recoveries of P-Ser and P-Thr were obtained at $110^{\circ} \mathrm{C}$ for $2-3 \mathrm{hr}$, these conditions being in agreement with those reported previously: ${ }^{22}$ Under these conditions, P-Ser was detected as over 70 times more than P-Thr in phosvitin, while P-Tyr was not detected at all. On the other hand, the phosphate linkage of the tyrosine residue is far more resistant to base than to acid hydrolysis. P-Tyr tolerated the 


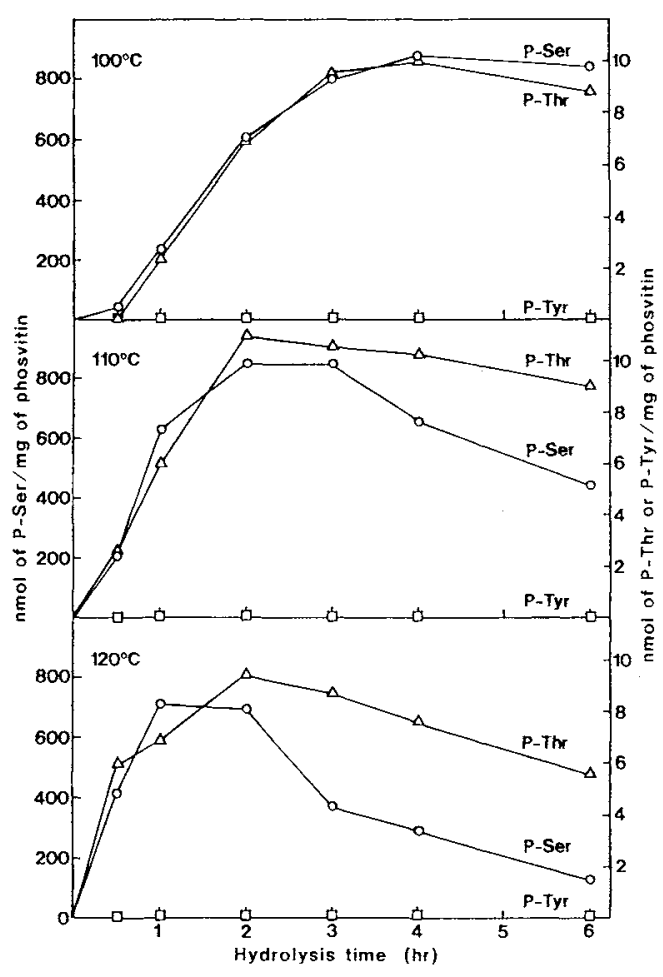

Fig. 3. Release of $O$-Phosphoamino Acids from Phosvitin by Acid Hydrolysis.

base hydrolysis fairly well in $5 \mathrm{M} \mathrm{KOH}$ at $155^{\circ} \mathrm{C}$ for $30-35 \mathrm{~min}^{3,14)}$ In our experiments, the maximal recovery of $\mathrm{P}-\mathrm{Tyr}$ from phosvitin was obtained in $5 \mathrm{M} \mathrm{KOH}$ at $130^{\circ} \mathrm{C}$ for $0.5-4 \mathrm{hr}$ (Fig. 4). Because the P-Ser, P-Thr and P-Tyr residues in protein were completely destroyed by base hydrolysis in $5 \mathrm{M} \mathrm{KOH}$ at $150^{\circ} \mathrm{C}$ for $6 \mathrm{hr}$, the hydrolysate yielding the phosphate was measured as the total phosphate content in protein. Under the best conditions for acid hydrolysis, the recovery of P-Ser from phosvitin was calculated to be $35.7 \pm 1.5 \% \quad(n=$ 3 ) by measuring the total phosphate content. The recovery of P-Ser from $\alpha$-casein was $39.5 \pm 4.1 \% \quad(n=3)$ under the same conditions. These low recoveries seem to have been due to both incomplete peptide hydrolysis and destruction of the liberated P-Ser to serine. The typical recovery for proteins has been reported to be in the range $20-30 \%{ }^{19)}$ Our results presented here are generally somewhat higher, the recoveries may show some de-

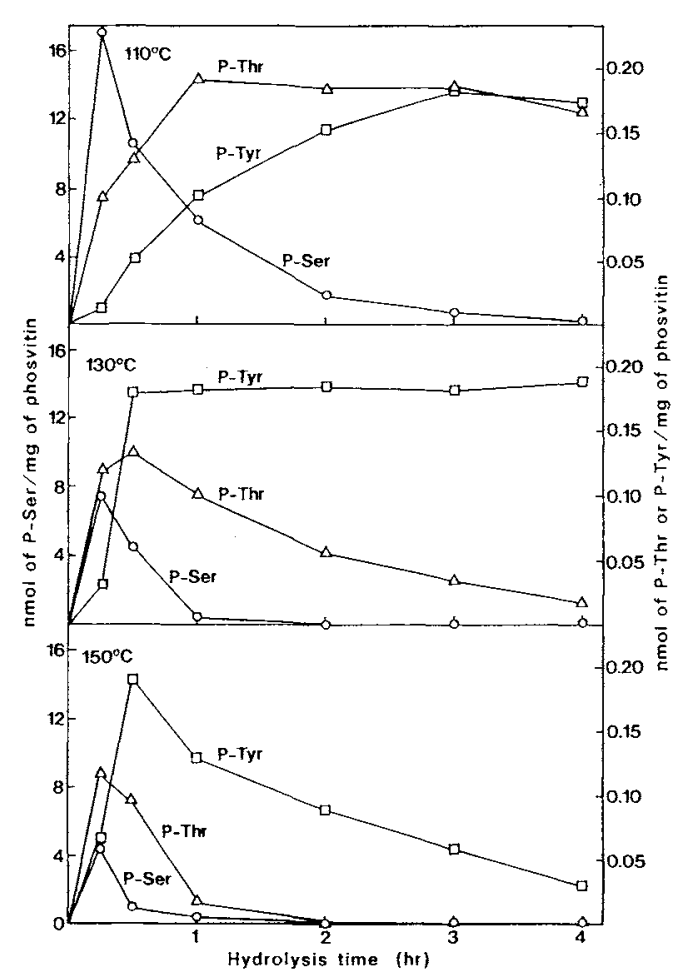

Fig. 4. Release of $O$-Phosphoamino Acids from Phosvitin by Base Hydrolysis.

pendence on the neighboring amino acid residues. $^{29)}$

\section{O-Phosphoamino acid analysis for several proteins}

Several commercial proteins were analyzed for the presence of $O$-phosphoamino acid residues by using this method. As shown in Figs. $1-\mathrm{B} \sim \mathrm{D}$ and $2-\mathrm{B} \sim \mathrm{D}, O$-phosphoamino acids in the protein hydrolysates were selectively detected without any influence from other amino acids by FPD-GC. The results of $O$-phosphoamino acid analyses of the protein samples after partial acid and base hydrolysis are shown in Table I. P-Ser was detected in all the samples investigated in this study, except for bovine serum albumin. Assuming a molecular weight of 23,500 for $\alpha$ casein, the molar ratio of P-Ser $/ \alpha$-casein was calculated to be 3.2 , a value in agreement with that reported previously. ${ }^{25)}$ The yields of P-Ser from ovalbumin $(\mathrm{MW}=45,000)$, 
Table I. O-Phosphoamino Acid Analysis of Several Commercial Proteins by Partial Acid and Base Hydrolysis

\begin{tabular}{lccc}
\hline \multirow{2}{*}{ Protein } & \multicolumn{3}{c}{ O-Phosphoamino acid (nmol/mg of protein $)^{a}$} \\
\cline { 2 - 4 } & P-Ser $^{b}$ & P-Thr & P-Tyr $^{b}$ \\
\hline Albumin & $\mathrm{ND}^{d}$ & $\mathrm{ND}$ & $\mathrm{ND}$ \\
Ovalbumin & $7.74 \pm 0.51$ & $\mathrm{ND}$ & $\mathrm{ND}$ \\
$\alpha$-Casein & $137.30 \pm 14.20$ & $0.69 \pm 0.04$ & $0.073 \pm 0.004$ \\
$\beta$-Casein & $104.28 \pm 4.87$ & $0.16 \pm 0.01$ & $0.013 \pm 0.001$ \\
$\kappa$-Casein & $67.26 \pm 0.89$ & $0.87 \pm 0.01$ & $0.071 \pm 0.002$ \\
Phosvitin & $848.14 \pm 35.81$ & $11.06 \pm 0.75$ & $0.182 \pm 0.010$ \\
Hemoglobin & $0.03 \pm 0.002$ & $\mathrm{ND}$ & $\mathrm{ND}$ \\
Cytochrome $c$ & $0.08 \pm 0.002$ & $\mathrm{ND}$ & $\mathrm{ND}$ \\
Protamine & $1.46 \pm 0.07$ & $\mathrm{ND}$ & $\mathrm{ND}$ \\
Histone & $0.30 \pm 0.01$ & $0.04 \pm 0.002$ & $\mathrm{ND}$ \\
Myelin basic protein & $3.93 \pm 0.28$ & $1.00 \pm 0.06$ & $\mathrm{ND}$ \\
Alcohol dehydrogenase & $0.07 \pm 0.004$ & $\mathrm{ND}$ & $\mathrm{ND}$ \\
Catalase & $0.17 \pm 0.01$ & $0.04 \pm 0.001$ & $\mathrm{ND}$ \\
Lysozyme & $0.05 \pm 0.003$ & $\mathrm{ND}$ & $\mathrm{ND}$ \\
Chymotrypsin & $0.13 \pm 0.01$ & $\mathrm{ND}$ & \\
\hline
\end{tabular}

a $\quad$ Mean $\pm \operatorname{SD}(n=3)$.

$b$ Analyzed after partial acid hydrolysis.

c Analyzed after partial base hydrolysis.

d Not detectable.

$\beta$-casein $(\mathrm{MW}=24,000), \quad \kappa$-casein $\quad(\mathrm{MW}=$ $19,000)$ and phosvitin $(\mathrm{MW}=35,000)$ were $0.3,2.5,1.3$ and $29.7 \mathrm{~mol} / \mathrm{mol}$ protein, respectively, the P-Ser content in other proteins being very low. P-Thr was also detected in the $\alpha$-, $\beta$ - and $\kappa$-caseins, phosvitin, histone, myelin and catalase, but was not detected in the other proteins. The P-Thr content proved to be $0.4 \mathrm{~mol} / \mathrm{mol}$ of phosvitin, and those for the other proteins were below 0.02 $\mathrm{mol} / \mathrm{mol}$. A trace amount of P-Tyr was detected in phosvitin and in the $\alpha-, \beta$ - and $\kappa$ caseins, the P-Tyr content in these proteins proving to be below $0.01 \mathrm{~mol} / \mathrm{mol}$.

The results in this paper indicate that FPD-GC is extremely useful for the $O$ phosphoamino acid analysis of a number of non-radioactive phosphoproteins. The proposed method is highly selective and sensitive to $O$-phosphoamino acids, and directly applicable for analyzing the extent of endogenous phosphorylation at a particular site.

\section{References}

1) E. G. Krebs and J. A. Beavo, Ann. Rev. Biochem.,
48, 923 (1972).

2) P. Cohen, Proc. R. Soc. London, B234, 115 (1988).

3) T. M. Martensen, "Methods in Enzymology," Vol. 107 , ed. by F. Wold and K. Moldave, New York, 1984, p. 3.

4) C. F. B. Holmes, FEBS Lett., 215, 21 (1987).

5) K. Minaguchi, G. Madapallimattam and A. Bennick, Biochem. J., 250, 171 (1988).

6) M. Manai and A. J. Cozzone, Anal. Biochem., 124, 12 (1982).

7) W. C. Chang, M. L. Lee, C. K. Chou and S. C. Lee, Anal. Biochem., 132, 342 (1983).

8) S. Fazekas, I. Ovary and V. Szekessy-Hermann, Acta Physiol. Hung., 74, 161 (1989).

9) E. Neufeld, H. J. Goren and D. Boland, Anal. Biochem., 177, 138 (1989).

10) H. Ushiro and S. Cohen, J. Biol. Chem., 255, 8363 (1980).

1I) M. P. Kamps and B. M. Sefton, Anal. Biochem., 176, 22 (1989).

12) E. Hildebrandt and V. A. Fried, Anal. Biochem., 177, 407 (1989).

13) J. P. Capony and J. G. Demaille, Anal. Biochem., 128, 206 (1983).

14) T. M. Martensen, J. Biol. Chem., 257, 9648 (1982).

15) W. J. Kinnier and J. E. Wilson, J. Chromatogr, 135, 508 (1977).

16) A. W. Steiner, E. R. Helandes, J. M. Fujitaki, L. S. Smith and R. A. Smith, J. Chromatogr., 202, 263 (1980). 
17) J. C. Yang, J. M. Fujitaki and R. A. Smith, Anal. Biochem., 122, 360 (1982).

18) D. T. Pang, D. S. Lewis, B. R. Sharma and J. A. Shafer, Arch. Biochem. Biophys., 234, 629 (1984).

19) N. Morrice and A. Aitken, Anal. Biochem., 148, 207 (1985).

20) L. Carlomagno, V. D. Huebner and H. R. Matthews, Anal. Biochem., 149, 344 (1985).

21) D. W. McCourt, J. F. Leykam and B. D. Schwartz, J. Chromatogr, 327, 9 (1985)

22) J. C. Robert, A. Soumarmon and M. J. M. Lewin, J. Chromatogr., 338, 315 (1985).

23) J. S. Niedbalski and D. P. Ringer, Anal. Biochem.,
158, 138 (1986)

24) M. C. McCroskey, J. R. Colca and J. D. Pearson, J. Chromatogr., 442, 307 (1988).

25) D. A. Malencik, Z. Zhao and S. R. Anderson, Anal. Biochem., 184, 353 (1990).

26) H. Kataoka, N. Sakiyama and M. Makita, $J$. Chromatogr., 436, 67 (1988).

27) H. Schlenk and J. L. Gellerman, Anal. Chem., 32 , $1412(1960)$.

28) K. Itaya and M. Ui, Clin. Chim. Acta, 14,361 (1966).

29) D. B. Bylund and T. S. Huang, Anal. Biochem., 73, 477 (1976). 